\title{
Analisis parameter pertumbuhan itik Magelang generasi ketiga di Balai Pembibitan Ternak Non Ruminansia Satuan Kerja itik Banyubiru
}

\author{
Elisabeth Nadia Yusinta, Edy Kurnianto, Sutopo \\ Fakultas Peternakan dan Pertanian Universitas Diponegoro Semarang \\ Correspondence author: elisabethnadia95@gmail.com
}

\begin{abstract}
The aim of this research was to determine growth curve models of the third generation Magelang ducks using Gompertz and Logistic Growth Model. Individual body weight was obtained by weighing at every three days from 0 to 60 days. Growth parameters were analyzed by nonlinear Gompertz and Logistic models using SAS v6.12 program. The results showed that the growth curve models had different levels of accuracy, regression models equation of Gompertz at male was $Y=2031.047$ $\exp (-3.475$ exp-0.03), female was $\mathrm{Y}=1711.909 \exp (-3.374$ exp-0.04), whereas regression models equation of Logistic at male was $\mathrm{Y}=1525.168 /(1+14.996$ exp-0.07), and female was $\mathrm{Y}=1387.704 /(1+13.893$ exp-0.08). Growth rate constant $(\mathrm{k})$ of Gompertz model was lower than the Logistic model, whereas Gompertz's asymptotic mature weight (A) was higher than Logistic model. Gompertz shows the smaller number of R2 dan AIC it was 0.9997 and 110.227, whilst Logistic 0.9987 and 143.917. Inflection point for Gompertz model at male, female and unisex ducks were indicated by age $\left(\mathrm{Y}_{\mathrm{i}}\right)$ and weight $\left(\mathrm{t}_{\mathrm{i}}\right)$ at inflection point, there were: $\mathrm{Y}_{\mathrm{i}}=932.408 \mathrm{~g}, \mathrm{t}_{\mathrm{i}}=35.798$ day; $\mathrm{Y}_{\mathrm{i}}=785.899 \mathrm{~g}, \mathrm{t}_{\mathrm{i}}=30.586$ day; and $\mathrm{Y}_{\mathrm{i}}=856.572 \mathrm{~g}, \mathrm{t}_{\mathrm{i}}=33.177$ day, respectively whilst Logistic was $\mathrm{Y}_{\mathrm{i}}=762.584 \mathrm{~g}, \mathrm{t}_{\mathrm{i}}=36.470$ day; $\mathrm{Y}_{\mathrm{i}}=689.352 \mathrm{~g}, \mathrm{t}_{\mathrm{i}}=33.209$ day; and $\mathrm{Y}_{\mathrm{i}}=726.014 \mathrm{~g}, \mathrm{t}_{\mathrm{i}}=34.890$ day, respectively. In conclusion, inflection point and calibration of $\mathrm{R}^{2}$ and AIC concluded that Gompertz models were greater to represent growth patterns of third generation Magelang ducks rather than Logistic models.
\end{abstract}

Keywords: Magelang duck, growth models, $\mathrm{R}^{2}$, AIC, inflection point

\section{PENDAHULUAN}

Plasma nutfah atau sumber daya genetik ternak merupakan unsur yang terdapat dalam kelompok makhluk hidup dan merupakan sumber sifat keturunan pada individu yang dapat dimanfaatkan dan dikembangkan untuk pembentukan galur unggul maupun galur baru untuk memenuhi kebutuhan pangan manusia (Setioko et al., 2014). Pembentukan galur unggul atau pemuliaan ternak bermanfaat penting untuk menjaga sumber daya genetik ternak. Berdasarkan SK Menteri
Pertanian No. 701/Kpts/PD.410/2/2013, itik Magelang telah ditetapkan sebagai rumpun itik lokal Indonesia dan sebagai sumber daya genetik ternak lokal Indonesia (Kementrian Pertanian, 2013). Itik Magelang memiliki bulu kecoklatan dengan ciri khas yaitu bulu berwarna putih yang melingkar pada leher setebal 1-2 cm menyerupai kalung sehingga sering disebut sebagai itik kalung (Magfiroh et al., 2012). Keunggulan Itik Magelang terletak pada produksi telurnya yang mencapai 250300 butir telur/tahun (Mahfudz et al., 
2005). Bobot dewasa itik Magelang jantan berkisar 1,8-2,5 $\mathrm{kg}$ sedangkan untuk itik betina 1,5-2,0 kg (Kementrian Pertanian, 2013). Bobot badan adalah satu sifat kuantitatif yang dapat menggambarkan pola pertumbuhan itik Magelang dan menjadi tolak ukur kualitas genetik dari itik Magelang. Untuk menggambarkan pola pertumbuhan itik Magelang yang tepat, perlu dilakukan analisis menggunakan beberapa model pertumbuhan.

Model pertumbuhan adalah salah satu model regresi nonlinier yang digunakan untuk menggambarkan perilaku pertumbuhan karena peubah pada pertumbuhan cenderung berkorelasi satu dengan yang lain (Anindita et al., 2014). Beberapa model pertumbuhan yang paling sering digunakan adalah Brody, Richard, Logistic, von Bertalanffy dan Gompertz. Model pertumbuhan ini sering digunakan karena relatif mudah dalam peroses perhitungan dan mempunyai kemampuan yang baik dalam menjelaskan data di lapangan dengan akurat serta dapat menjelaskan titik infleksi (Salman et al., 2015), dari sekian banyak model pertumbuhan, model Gompertz dan Logistic dipilih untuk menganalisis pertumbuhan itik Magelang generasi ketiga. Manfaat penelitian ini yaitu memberikan informasi pola pertumbuhan yang tepat pada itik Magelang generasi ketiga di Balai Pembibitan Ternak Non Ruminansia Satuan Kerja Itik Banyubiru dari umur 0 sampai 2 bulan (60 hari).

\section{MATERI DAN METODE}

Penelitian ini telah dilaksanakan pada bulan Maret hingga November 2016 di Balai Pembibitan Ternak Non Rumunansia Satuan Kerja Itik
Banyubiru, Kabupaten Semarang, Jawa Tengah. Analisis data dilaksanakan di Laboratorium Genetika, Pemuliaan dan Reproduksi Fakultas Peternakan dan Pertanian Universitas Diponegoro, Semarang.

\section{Materi penelitian}

Materi yang digunakan dalam penelitian ini adalah anak-anak keturunan G2, yaitu itik Magelang generasi ke-3 (G3) yang ditetaskan, berumur 1 - 60 hari. Alat yang digunakan dalam penelitian adalah mesin setter dan hatcer untuk menetaskan telur, box sebagai tempat telur yang dimasukkan ke dalam mesin hatcher dan memindahkan itik yang baru menetas ke kandang DOD, kabel ties dan label sebagai media recording, tempat pakan dan minum, timbangan digital untuk menimbang bobot badan itik, kandang induk dan DOD, lampu sebagai penerangan dan juga penghangat DOD dan alat tulis untuk mencatat data penelitian.

\section{Metode penelitian}

Penelitian ini dilaksanakan dalam tiga tahap, yaitu (1) Pra penelitian yang meliputi kegiatan persiapan penelitian. (2) Pengambilan data meliputi penimbangan itik Magelang setiap 3 hari sekali dari umur 0 sampai 60 hari dan sexing.(3) Analisis data pertumbuhan menggunakan model gompertz dan logistic dengan aplikasi SAS v6.12

Data bobot badan itik Magelang
G3 yang diperoleh, dianalisis
menggunakan program SAS dengan persamaan regresi non linier model Gompertz dan Logistic serta ditentukan titik infleksinya (Kurnianto el al., 1997). Persamaan matematik yang digunakan adalah sebagai berikut :

Model Pertumbuhan Persamaan Titik Infleksi 


\begin{tabular}{cccc}
\cline { 2 - 3 } & & $\mathrm{t}_{\mathrm{i}}$ & $\mathrm{Y}_{\mathrm{i}}$ \\
\hline Gompertz & $\mathrm{Y}=\mathrm{A} \exp \left(-\mathrm{Be}^{-\mathrm{kt}}\right)$ & $\left(\mathrm{e}^{-1} \mathrm{~A}\right)$ & $(\ln \mathrm{B}) / \mathrm{k}$ \\
Logistic & $\mathrm{Y}=\mathrm{A} /\left(1+\mathrm{Be}^{-\mathrm{kt}}\right)^{-\mathrm{M}}$ & $(1 / 2 \mathrm{~A})$ & $(\ln \mathrm{B}) / \mathrm{k}$ \\
\hline
\end{tabular}

Keterangan : $\mathrm{Y}=$ Ukuran tubuh ternak pada waktu $\mathrm{t}$

A = Ukuran dewasa tubuh (asimtot) untuk bobot hidup

$\mathrm{B}=$ Parameter skala (nilai konstanta)

e = Logaritma dasar $(2,178282)$

$\mathrm{k}=$ Rataan laju pertumbuhan hingga ternak mencapai dewasa tubuh

$\mathrm{t}=$ Satuan waktu (umur)

$\mathrm{M}=$ Nilai yang berfungsi dalam pencarian titik infleksi

Tingkat keakuratan hasil analisis pertumbuhan pada kedua model diketahui dengan menghitung nilai koefisien determinasi (R2) dan Akaike's Information Criterion (AIC) (Fathurahman, 2009) sebagai berikut :

AIC $=\frac{2 k}{n}+\ln \left[\frac{\sum_{i=1}^{n} u_{i}{ }^{2}}{n}\right]$

Keterangan : $\mathrm{k}=$ Jumlah parameter yang diestimasi dalam model regresi

$\mathrm{n}=$ Jumlah observasi

$u=$ Sisa (residual)

\section{HASIL DAN PEMBAHASAN}

\section{Persamaan model kurva pertumbuhan}

Persamaan model regresi pertumbuhan itik Magelang tanpa pemisahan flock menggunakan model Gompertz dan Logistic disajikan dalam Tabel 2. Pada model Gompertz dan Logistic, itik Jantan memiliki bobot dewasa yang terbesar, itik betina memiliki bobot dewasa terkecil dan itik unsex berada di tengah keduanya. Secara keseluruhan bobot dewasa tubuh pada model Gompertz lebih tinggi dibandingkan dengan model Logistic sedangkan laju pertumbuhannya yang lebih lambat. Semakin kecil nilai laju pertumbuhan, maka semakin besar bobot dewasa. Itik dengan laju pertumbuhan yang kecil akan lambat dalam mencapai dewasa kelamin, sehingga memiliki bobot dewasa tubuh yang lebih besar.Analisis bobot dewasa menggunakan model Gompertz lebih sesuai dengan standar kementrian Pertanian (2013) dimana bobot dewasa itik Magelang jantan berkisar 1,8 - 2,5 $\mathrm{kg}$ sedangkan untuk itik betina 1,5 - 2,0 kg. Kurnianto et al. (1998), menyatakan bahwa nilai $\mathrm{k}$ yang lebih besar mengindikasikan ternak lebih cepat mencapai dewasa tubuh sedangkan nilai $\mathrm{k}$ yang lebih kecil berarti mencapai dewasa tubuh lebih lambat. 
Tabel 2. Persamaan Model Pertumbuhan Itik Magelang Berdasar Jenis Kelamin dan Unsex

\begin{tabular}{ccc}
\hline Jenis & \multicolumn{2}{c}{ Persamaan Model Regresi } \\
\cline { 2 - 3 } Kelamin & Gompertz & Logistic \\
\hline Unsex & $\mathrm{Y}=1865,856 \exp \left(-3,421 \exp ^{-0,04}\right)$ & $\mathrm{Y}=1452,027 /\left(1+14,415 \exp ^{-0,08}\right)$ \\
Jantan & $\mathrm{Y}=2031,047 \exp \left(-3,475 \exp ^{-0,03}\right)$ & $\mathrm{Y}=1525,168 /\left(1+14,996 \exp ^{-0,07}\right)$ \\
Betina & $\mathrm{Y}=1711,909 \exp \left(-3,374 \exp ^{-0,04}\right)$ & $\mathrm{Y}=1387,704 /\left(1+13,893 \exp ^{-0,08}\right)$ \\
\hline
\end{tabular}

Keterangan: A : bobot dewasa $(\mathrm{g})$

B : nilai konstanta

$\mathrm{k}$ : laju pertumbuhan

\section{Analisis pertumbuhan}

Hasil analisis pertumbuhan berupa bobot dugaan itik Magelang jantan, betina dan unsex disajikan dalam Tabel 3. Diketahui rata-rata simpangan pertumbuhan itik Magelang betina adalah yang terkecil yaitu $-0,98$ dan 3,47 pada model Gompertz dan Logistic. Jika dibandingkan, rata-rata simpangan model Gompertz nilanya jauh lebih kecil dibandinkan model Logistic meskipun keduanya sama-sama overestimate. Simpangan data terlihat dalam kurva pertumbuhan (Gambar 1 Gambar 6). Itik jantan diketahui memiliki bobot akhir yang lebih besar

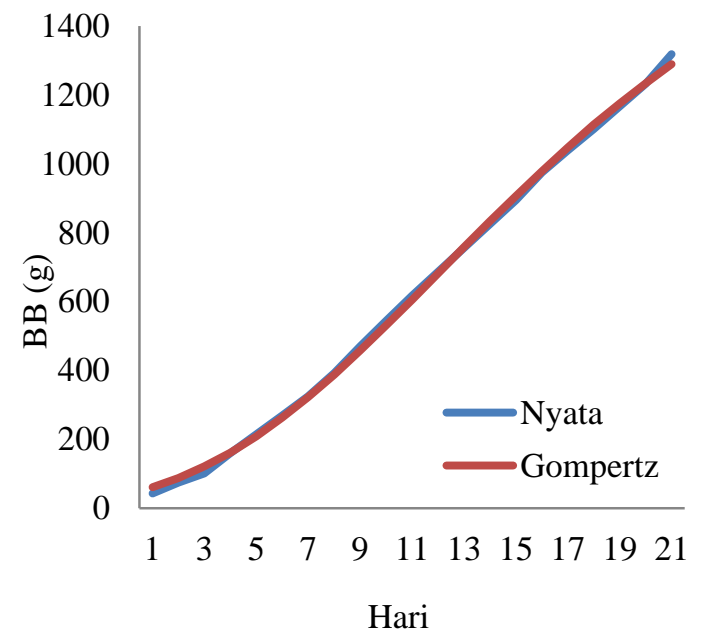

Gambar 1. Kurva pertumbuhan bobot badan nyata dan dugaan itik Magelang unsex model Gompertz dari itik betina, sedangkan itik unsex yang merupakan campuran keduanya berada ditengah. Hal ini serupa dengan hasil penelitian Syaifudin et al. (2015) menggunakan itik Alabio, dimana rataan bobot itik umur 8 minggu berdasarkan jenis kelamin menunjukkan bahwa itik jantan memiliki bobot yang lebih besar dari itik betina karena itik jantan memiliki hormon androgen lebih banyak dari itik betina, selain itu itik jantan memiliki kemampuan memanfaatkan (efisiensi) pakan yang lebih baik sehingga memiliki pertumbuhan dan bobot potong yang lebih besar.

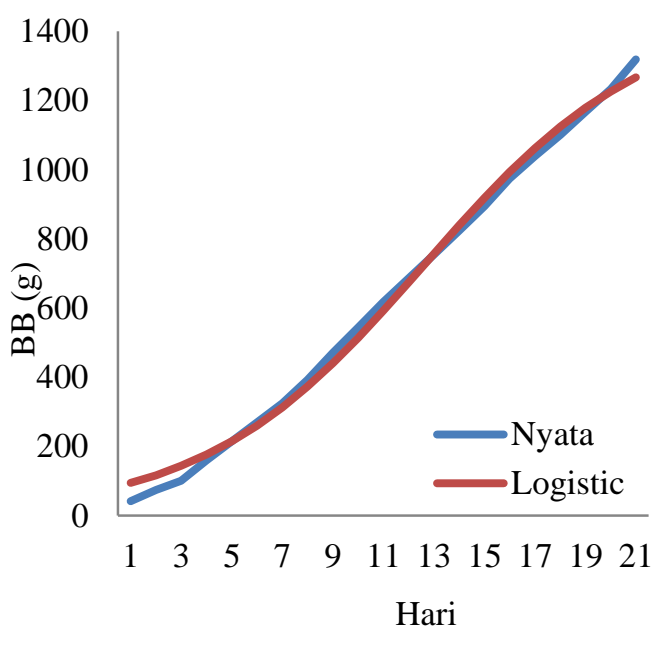

Gambar 2. Kurva pertumbuhan bobot badan nyata dan dugaan itik Magelang unsex model Logistic 


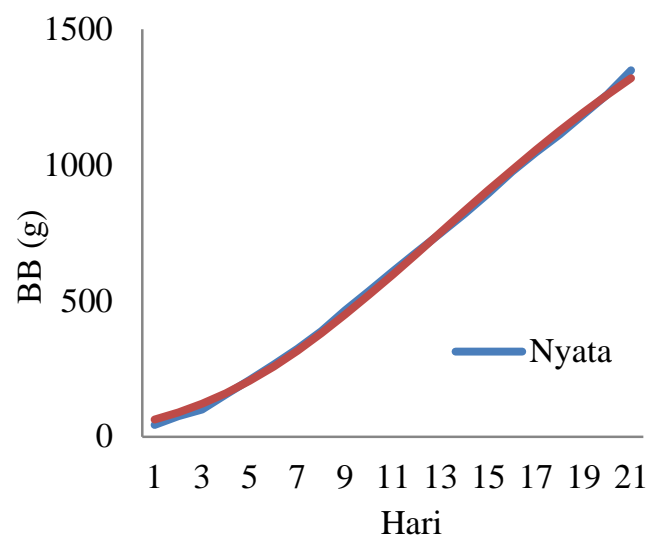

Gambar 3. Kurva pertumbuhan bobot badan nyata dan dugaan itik Magelang jantan model Gompertz

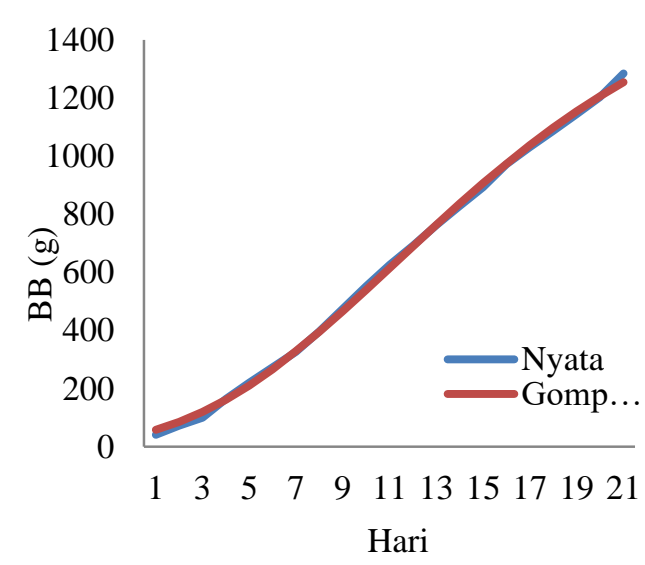

Gambar 5. Kurva pertumbuhan bobot badan nyata dan dugaan itik Magelang betina model Gompertz

Pertumbuhan bobot badan nyata dan dugaan itik Magelang unsex menggunakan model Gompertz dan Logistic menghasilkan kurva pertumbuhan yang disajikan dalam Gambar 1 sampai Gambar 6. Grafik antara bobot nyata dan dugaan saling berhimpit, jika diperhatikan lebih seksama grafik pertumbuhan menggunakan model Gompertz lebih berhimpit dibanding nodel Logistic. Hal ini menunjukkan bahwa bobot dugaan hasil analisis model Gompertz lebih mendekati bobot nyata. Kurva

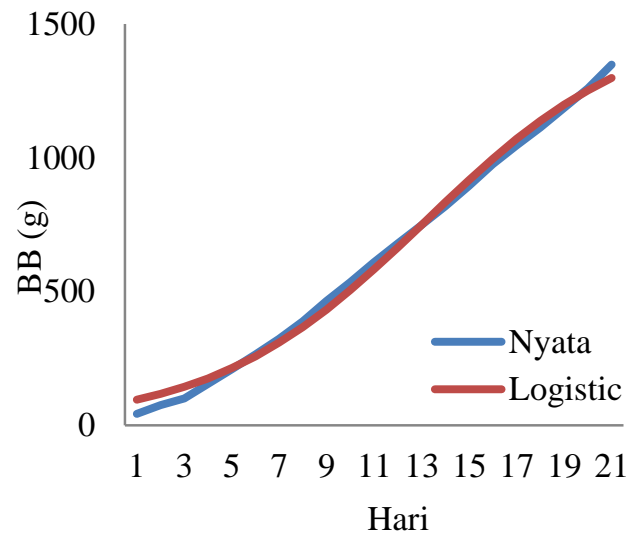

Gambar 4. Kurva pertumbuhan bobot badan nyata dan dugaan itik Magelang jantan model Logistic

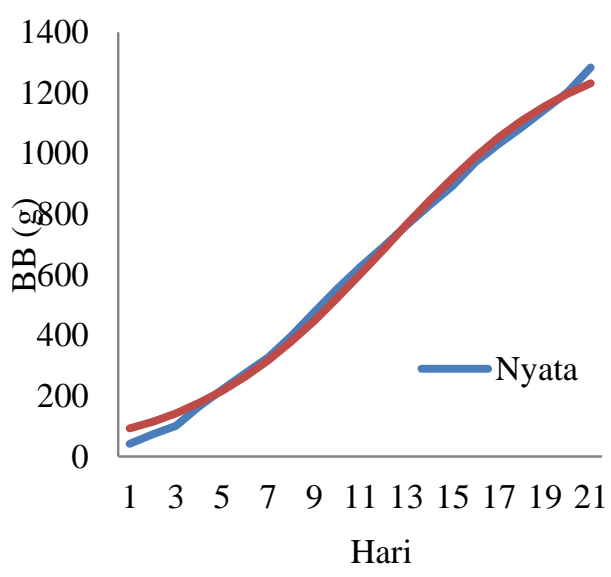

Gambar 6. Kurva pertumbuhan bobot badan nyata dan dugaan itik Magelang betina model Logistic

pertumbuhan postnatal ternak seharusnya berbentuk sigmoid (bentuk S) namun, grafik pada itik jantan, betina dan unsex dari kedua model analisis belum berbentuk kurva sigmoid, hal ini kemungkinan terjadi karena waktu pengambilan data pertumbuhan yang hanya sampai 60 hari (9 minggu). Dijelaskan pada penelitian Susanti dan Prasetyo (2007) terhadap itik Alabio, pertumbuhan itik membentuk kurva sigmoid dengan data pertumbuhan hingga 16 minggu. 
Tabel 3. Bobot Badan Nyata dan Dugaan Itik Magelang G3 Menggunakan Model Gompertz dan Logistic

\begin{tabular}{|c|c|c|c|c|c|c|c|c|c|c|c|c|c|c|c|}
\hline \multirow{3}{*}{ Umur } & \multicolumn{5}{|c|}{ Unsex } & \multicolumn{5}{|c|}{ Jantan } & \multicolumn{5}{|c|}{ Betina } \\
\hline & \multirow{2}{*}{$\begin{array}{c}\text { BB } \\
\text { Nyata }\end{array}$} & \multicolumn{2}{|c|}{ Gompertz } & \multicolumn{2}{|c|}{ Logistic } & \multirow{2}{*}{$\begin{array}{c}\text { BB } \\
\text { Nyata }\end{array}$} & \multicolumn{2}{|c|}{ Gompertz } & \multicolumn{2}{|c|}{ Logistic } & \multirow{2}{*}{$\begin{array}{c}\text { BB } \\
\text { Nyata }\end{array}$} & \multicolumn{2}{|c|}{ Gompertz } & \multicolumn{2}{|c|}{ Logistic } \\
\hline & & $\begin{array}{c}\text { BB } \\
\text { Dugaan }\end{array}$ & $\Delta$ & $\begin{array}{c}\text { BB } \\
\text { Dugaan }\end{array}$ & $\Delta$ & & $\begin{array}{c}\text { BB } \\
\text { Dugaan }\end{array}$ & $\Delta$ & $\begin{array}{c}\text { BB } \\
\text { Dugaan }\end{array}$ & $\Delta$ & & $\begin{array}{c}\text { BB } \\
\text { Dugaan }\end{array}$ & $\Delta$ & $\begin{array}{c}\text { BB } \\
\text { Dugaan }\end{array}$ & $\Delta$ \\
\hline hari & & 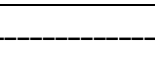 & ----- g --- & (2) & & & (- & ---- g - - & 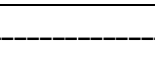 & & - & - & - $g$ & (- & \\
\hline 0 & 42,10 & 60,99 & $-18,89$ & 94,20 & $-52,10$ & 42,39 & 62,87 & $-20,48$ & 95,35 & $-52,96$ & 41,78 & 58,66 & $-16,88$ & 92,58 & $-50,80$ \\
\hline 3 & 74,31 & 87,42 & $-13,12$ & 116,54 & $-42,23$ & 75,20 & 88,73 & $-13,53$ & 117,30 & $-42,11$ & 73,32 & 85,71 & $-12,39$ & 115,34 & $-42,02$ \\
\hline 6 & 100,53 & 120,65 & $-20,12$ & 143,62 & $-43,09$ & 100,40 & 121,02 & $-20,62$ & 143,81 & $-43,41$ & 100,67 & 120,02 & $-19,35$ & 143,08 & $-42,41$ \\
\hline 9 & 159,50 & 160,96 & $-1,46$ & 176,16 & $-16,67$ & 154,94 & 160,05 & $-5,12$ & 175,56 & $-20,62$ & 164,54 & 161,82 & 2,72 & 176,56 & $-12,02$ \\
\hline 12 & 215,01 & 208,31 & 6,69 & 214,87 & 0,14 & 209,26 & 205,89 & 3,36 & 213,24 & $-3,99$ & 221,37 & 210,96 & 10,40 & 216,49 & 4,88 \\
\hline 15 & 269,35 & 262,38 & 6,97 & 260,35 & 9,00 & 264,98 & 258,33 & 6,65 & 257,46 & 7,51 & 274,19 & 266,96 & 7,23 & 263,48 & 10,70 \\
\hline 18 & 325,05 & 322,55 & 2,50 & 313,01 & 12,04 & 323,70 & 316,92 & 6,78 & 308,70 & 15,00 & 326,55 & 328,99 & $-2,44$ & 317,88 & 8,66 \\
\hline 21 & 392,24 & 388,00 & 4,24 & 373,00 & 19,24 & 388,49 & 380,99 & 7,49 & 367,18 & 21,31 & 396,40 & 396,02 & 0,38 & 379,69 & 16,70 \\
\hline 24 & 470,28 & 457,74 & 12,54 & 440,03 & 30,25 & 464,78 & 449,74 & 15,04 & 432,79 & 31,99 & 476,36 & 466,87 & 9,49 & 448,44 & 27,92 \\
\hline 27 & 543,87 & 530,69 & 13,18 & 513,39 & 30,48 & 535,14 & 522,23 & 12,91 & 505,02 & 30,12 & 553,54 & 540,31 & 13,23 & 523,11 & 30,42 \\
\hline 30 & 617,25 & 605,78 & 11,47 & 591,82 & 25,42 & 609,39 & 597,49 & 11,89 & 582,87 & 26,52 & 625,94 & 615,11 & 10,83 & 602,18 & 23,77 \\
\hline 33 & 685,95 & 681,92 & 4,02 & 673,64 & 12,31 & 679,71 & 674,54 & 5,18 & 664,89 & 14,82 & 692,85 & 690,13 & 2,71 & 683,64 & 9,21 \\
\hline 36 & 755,09 & 758,13 & $-3,04$ & 756,81 & $-1,72$ & 748,59 & 752,41 & $-3,82$ & 749,29 & $-0,70$ & 762,29 & 764,35 & $-2,06$ & 765,26 & $-2,97$ \\
\hline 39 & 823,99 & 833,51 & $-9,52$ & 839,18 & $-15,19$ & 819,30 & 830,24 & $-10,94$ & 834,01 & $-14,70$ & 829,17 & 836,88 & $-7,71$ & 844,78 & $-15,61$ \\
\hline 42 & 894,70 & 907,29 & $-12,59$ & 918,67 & $-23,97$ & 895,41 & 907,23 & $-11,81$ & 916,98 & $-21,57$ & 893,91 & 907,01 & $-13,09$ & 920,18 & $-26,26$ \\
\hline 45 & 974,39 & 978,82 & $-4,43$ & 993,49 & $-19,10$ & 976,62 & 982,67 & $-6,06$ & 996,31 & $-19,70$ & 971,92 & 974,15 & $-2,24$ & 989,82 & $-17,90$ \\
\hline
\end{tabular}


Tabel 3. (lanjutan)

\begin{tabular}{|c|c|c|c|c|c|c|c|c|c|c|c|c|c|c|c|}
\hline \multirow{3}{*}{ Umur } & \multicolumn{5}{|c|}{ Unsex } & \multicolumn{5}{|c|}{ Jantan } & \multicolumn{5}{|c|}{ Betina } \\
\hline & \multirow{2}{*}{$\begin{array}{c}\text { BB } \\
\text { Nyata }\end{array}$} & \multicolumn{2}{|c|}{ Gompertz } & \multicolumn{2}{|c|}{ Logistic } & \multirow{2}{*}{$\begin{array}{c}\text { BB } \\
\text { Nyata }\end{array}$} & \multicolumn{2}{|c|}{ Gompertz } & \multicolumn{2}{|c|}{ Logistic } & \multirow{2}{*}{$\begin{array}{c}\text { BB } \\
\text { Nyata }\end{array}$} & \multicolumn{2}{|c|}{ Gompertz } & \multicolumn{2}{|c|}{ Logistic } \\
\hline & & $\begin{array}{c}\text { BB } \\
\text { Dugaan }\end{array}$ & $\Delta$ & $\begin{array}{c}\text { BB } \\
\text { Dugaan }\end{array}$ & $\Delta$ & & $\begin{array}{c}\text { BB } \\
\text { Dugaan }\end{array}$ & $\Delta$ & $\begin{array}{c}\text { BB } \\
\text { Dugaan }\end{array}$ & $\Delta$ & & $\begin{array}{c}\text { BB } \\
\text { Dugaan }\end{array}$ & $\Delta$ & $\begin{array}{c}\text { BB } \\
\text { Dugaan }\end{array}$ & $\Delta$ \\
\hline hari & - & (-ב-_- & --- & . & & - & (- & - $g$-- & (- & -- & - & - & $---g$ & - & -- \\
\hline 48 & 1039,13 & 1047,59 & $-8,46$ & 1062,26 & $-23,13$ & 1046,20 & 1056,00 & $-9,80$ & 1070,43 & $-24,23$ & 1031,30 & 1037,90 & $-6,60$ & 1052,64 & $-21,34$ \\
\hline 51 & 1100,43 & 1113,21 & $-12,78$ & 1124,12 & $-23,69$ & 1112,86 & 1126,73 & $-13,87$ & 1138,19 & $-25,33$ & 1086,68 & 1097,97 & $-11,29$ & 1108,08 & $-21,40$ \\
\hline 54 & 1166,50 & 1175,39 & $-8,89$ & 1178,69 & $-12,19$ & 1186,06 & 1194,50 & $-8,44$ & 1198,94 & $-12,88$ & 1144,86 & 1154,19 & $-9,33$ & 1156,09 & $-11,23$ \\
\hline 57 & 1232,66 & 1233,98 & $-1,32$ & 1226,01 & 6,65 & 1259,69 & 1259,03 & 0,66 & 1252,43 & 7,26 & 1202,73 & 1206,50 & $-3,77$ & 1196,98 & 5,75 \\
\hline 60 & 1318,37 & 1288,86 & 29,51 & 1266,42 & 51,95 & 1349,05 & 1320,15 & 28,90 & 1298,81 & 50,24 & 1284,40 & 1254,91 & 29,49 & 1231,32 & 53,08 \\
\hline \multicolumn{2}{|c|}{ Rata-rata } & & $-1,12$ & & $-3,60$ & & & $-1,22$ & & $-3,69$ & & & $-0,98$ & & $-3,47$ \\
\hline
\end{tabular}

Keterangan : $\Delta:$ simpangan 


\section{Titik infleksi}

Titik infleksi itik Magelang jantan, betina dan unsex tanpa pemisahan flock disajikan dalam Tabel 4. Titik infleksi model Gompertz dan Logistic paling awal terjadi pada itik betina dengan bobot terendah yaitu $785,899 \mathrm{~g}$ dan $689,352 \mathrm{~g}$, titik infleksi paling lama terjadi pada itik jantan dengan bobot badan tertinggi yaitu $932,408 \mathrm{~g}$ dan 762,584 g. Jika dibandingkan antara model Gompertz dan Logistic secara keseluruhan, model Gompertz memiliki titik infleksi yang lebih awal dan bobot badan yang lebih besar. Titik infleksi terjadi diantara hari ke-30 sampai ke-36 (minggu ke-5 dan ke-6). Hal ini serupa dengan hasil penelitian Syaifudin et al. (2015) terhadap itik Alabio, titik infleksi terjadi pada minggu ke-5 dan setelah itu mengalami penurunan pertumbuhan atau fase retardasi. Titik infleksi adalah titik awal adanya transisi dari pola pertumbuhan cepat menuju ke lambat yang juga menjadi pertanda bahwa ternak mulai memasuki masa pubertas. Menurut Kementrian Pertanian (2013), itik Magelang mencapai masa pubertas sekitar minggu ke-5 dan ke-6. Tazkia dan Anggraeni (2009) menyatakan, pada saat ternak mencapai umur pubertas laju pertumbuhan ternak akan mulai melambat setelah pubertas atau dengan kata lain laju pertumbuhan akan melambat setelah melewati titik infleksi.

Tabel 4. Titik Infleksi Pertumbuhan Itik Magelang G3 Tanpa Pemisahan Flock

\begin{tabular}{ccccccc}
\hline \multirow{2}{*}{ No. } & \multirow{2}{*}{ Keterangan } & \multicolumn{2}{c}{ Gompertz } & & \multicolumn{2}{c}{ Logistic } \\
\cline { 3 - 4 } \cline { 5 - 6 } \cline { 5 - 6 } & \multicolumn{2}{c}{$\mathrm{Y}_{\mathrm{i}}$} & $\mathrm{t}_{\mathrm{i}}$ & & $\mathrm{Y}_{\mathrm{i}}$ & $\mathrm{t}_{\mathrm{i}}$ \\
\hline & & $----\mathrm{g}-----$ & & & $-----\mathrm{g}-----$ & \\
1. & Unsex & 856,572 & 33,177 & & 726,014 & 34,890 \\
2. & Jantan & 932,408 & 35,798 & & 762,584 & 36,470 \\
3. & Betina & 785,899 & 30,586 & & 689,352 & 33,209 \\
\hline
\end{tabular}

Ket $: \mathrm{Y}_{\mathrm{i}}$ : bobot badan saat titik infleksi $(\mathrm{g})$

$t_{i}$ : waktu saat titik infleksi (hari)

\section{Koefisien determinasi $\left(\mathbf{R}^{2}\right)$ dan Akaike's Information Criterion (AIC)}

Hasil koefisien determinasi dan AIC itik Magelang jantan, betina dan unsex tanpa pemisahan flock disajikan dalam Tabel 5. Koefisien determinasi itik betina adalah yang tertinggi, pada model Gompertz yaitu 0,9998 sedangkan model Logistic 0,9988. Hasil rata-rata AIC model Gompertz juga lebih kecil dibanding model Logistic yaitu 110,227 dan 143,7917 nilai terkecil juga dihasilkan oleh itik betina. Semakin mendekati angka 1 nilai koefisien determinasi $\left(\mathrm{R}^{2}\right)$ dan semakin kecilnya nilai AIC menunjukkan semakin baik model analisis yang digunakan. Hal ini berarti model Gompertz lebih baik dibandingkan model Logistic dalam menganalisis kurva pertumbuhan itik Magelang. Hal ini serupa dengan hasil penelitian Wardhani dan Setiarini (2010) terhadap ayam broiler strain Lohmann yaitu hasil $\mathrm{R}^{2}$ untuk model Logistic diperoleh 98,1\% (jantan) dan 97,9\% (betina), sedangkan pada model Gompertz 99,7\% (jantan dan betina). Hal ini menunjukkan bahwa model Gompertz lebih baik dalam menggambarkan pola pertumbuhan jika dibandingkan dengan model Logistic. Anindita et al. (2014) menyatakan, $\mathrm{R}^{2}$ yang semakin 
mendekati $100 \%$ merupakan hasil yang semakin baik dan menurut Putri et al. (2014), model pertumbuhan yang memiliki hasil AIC yang lebih kecil adalah yang lebih baik.

Tabel 5. Koefisien Determinasi dan AIC Itik Magelang Berdasar Jenis Kelamin dan Unsex

\begin{tabular}{cccccc}
\hline \multirow{2}{*}{ Jenis Kelamin } & \multicolumn{2}{c}{ Koefisien determinasi $\left(\mathrm{R}^{2}\right)$} & & \multicolumn{2}{c}{ AIC } \\
\cline { 2 - 3 } \cline { 5 - 6 } & Gompertz & Logistic & & Gompertz & Logistic \\
\hline Unsex & 0,9997 & 0,9987 & & 110,176 & 144,042 \\
Jantan & 0,9997 & 0,9987 & & 112,063 & 144,731 \\
Betina & 0,9998 & 0,9988 & & 108,441 & 142,978 \\
Rata-rata & 0,9997 & 0,9987 & & 110,227 & 143,917 \\
\hline
\end{tabular}

\section{KESIMPULAN}

Berdasarkan hasil persamaan regresi, titik infleksi serta pengujian $\mathrm{R}^{2}$ dan AIC, disimpulkan bahwa Model Gompertz lebih baik dalam menggambarkan pola pertumbuhan itik Magelang generasi ketiga daripada model Logistic.

\section{DAFTAR PUSTAKA}

Anindita, A., N. W. S. Wardhani dan H. Kusdarwati. 2014. Pemilihan model Stannard dan Richards pada pertumbuhan bobot itik. J. Mahasiswa Statistik. 2 (6): 473476.

Kementrian Pertanian. 2013. Keputusan Menteri Pertanian Nomor 701/Kpts/PD.410/2/2013 tentang Penetapan Rumpun Itik Magelang. Kementrian Pertanian, Jakarta.

Kurnianto, E., A. Shinjo dan D. Suga. 1997. Comparison of the three growth curve models for describing the growth patterns in wild and laboratory mice. J. Vet. Epidemol. 1 (2) : 49-55.

Kurnianto, E., A. Shinjo dan D. Suga. 1998. Analysis of growth in intersubspesific crossing of mice using gompertz model. AJAS. 11 (1) : 84-88.

Magfiroh, K., I. Mangisah dan V. D. Y. B. Ismadi. 2012. Pengaruh penambahan sari jeruk nipis (Citrus aurantifolia) dalam ransum terhadap kecernaan protein kasar dan retensi nitrogen pada itik magelang jantan. J. Anim. Agric. 1 (1) : $669-683$.

Mahfudz. L.D, S. Kismiati dan T.A. Sarjana. 2005. Fenotipik dari Itik Magelang yang Produktif. Prosiding Seminar Nasional Teknologi Peternakan dan Veteriner. Bogor, 12-13 September 2005. Hal 779-785.

Putri, F. A., L. A. Soehono dan N. W. S. Wardhani. 2014. Menduga pertumbuhan bobot kelinci (Oryctolagus cuniculus) dengan model summacher dan gompertz. J. Mahasiswa Statistik. 2 (1) : 57-60.

Salman, L.B., C. Sumantri, R.R. Noor, A. Saefuddin dan C. Talib. 2015. Kurva pertumbuhan sapi Friesian Holstein dari lahir sampai siap kawin berdasarkan 
tingkat kelahiran. J. Vet. 16 (1) : $96-10$.

Setioko, A. R., L. H. Prasetyo dan B. Brahmantiyo. 2014. Karakteristik Produksi Telur Itik Bali sebagai Sumber Plasma Nutfah Ternak. JITV. 19 (3) : 14.

Susanti, T. Dan L. H. Prasetyo. 2007. Model regresi pertumbuhan dua generasi populasi ternak terseleksi itik Alabio. JITV. 12 (4) : 300-304.

Syaifudin, Rukmiasih dan R. Afnan. 2015. Performa itik Alabio jantan dan betina berdasarkan pengelompokan bobot tetas. J.
Ilmu Produksi dan Teknologi Hasil Peternakan. 3 (2) : $83-88$.

Tazkia, R. dan A. Anggraeni. 2009. Pola dan Estimasi Kurva Pertumbuhan Sapi Friesian Holstein di Wilayah Kerja Bagian Timur KPSBU Lembang. Prosiding Seminar Nasional Teknologi Peternakan dan Veteriner. Bogor, 13-14 Agustus 2009. Hal 121-135.

Wardhani, W.S. dan E.P.F. Setiarini. 2010. Menduga pertumbuhan bobot badan ayam broiler strain Lohmann dengan pedekatan model logistic dan gompertz. J. Vet. Med. 3 (2):105-108. 